\title{
Strategies of Beef Cattle Development Enterprise in Selected Areas of Bangladesh
}

\author{
P. K. Sarma ${ }^{1, *}$, S.K. Raha \\ ${ }^{1}$ Bangladesh Agricultural University Research System (BAURES), Bangladesh Agricultural University, Bangladesh \\ ${ }^{2}$ Department of Agribusiness and Marketing, Bangladesh Agricultural University, Bangladesh
}

Copyright $@ 2015$ Horizon Research Publishing All rights reserved.

\begin{abstract}
The study is an attempt to scrutinize the existing internal and external factors, alternative strategies and priorities of the strategies applied in enhancing beef cattle agribusiness at Pabna and Sirajganj districts in Bangladesh. The primary data of the study were collected by employing various methods including survey, FGD, KII and observation. The sample size was 180 which were selected through convenience sampling technique. The following analytical tools were employed (i)designing SWOT matrix using the EFE-IFE criterion (ii) evaluation the SWOT matrix using the SPACE matrix, and (iii) designing the quantitative strategic programming matrix (QSPM). By analyzing all the factors from SWOT matrix four strategies were designed to determine the beef cattle development enterprise. The best strategy was selected by using QSPM matrix. The results reveal that IFE is 2.610 , EFE is 2.438 and the total weighted score of 5.833 which indicates the potential opportunity for beef cattle development by their strengths and minimize their weaknesses. Based on the findings of the study a strategy is recommended for beef cattle development enterprise.
\end{abstract}

Keywords Beef Cattle Agribusiness, Strategies, IFE-EFE Matrix and SWOT Analysis

\section{Introduction}

Livestock agribusiness plays a significant role in our economy through contributing to poverty eradication by creating rural employment and to gear up the achievement of higher economic growth. Livestock is an integral component of agricultural economy of Bangladesh. Performing various functions as provisions of food, nutrition, income generation, savings, draft power, manure, fuel, transport and cultural function and earning foreign currency by exporting meat, hides and skin and value added waste products, etc. About $36 \%$ of the total animal protein comes from the livestock and the rest $64 \%$ come from poultry, fish and pluses. Bangladesh has huge number of livestock and poultry population with very high density but low productivity. The country has about 23.4 million cattle, 1.45 million buffalos, 25.6 million goats, 3.16 million sheep, 221.30 million chicken and 41.23 million ducks (Tareque at el. 2010) [1] Beef cattle are the important and potential sub-sector to economic development, where this sub-sector has a strategic value to fulfill the human need through progressively increase per capita income. The study aimed to examine the existing characteristics of the farmers, i.e. their social and economic characteristics in relation to the development of beef cattle farming, to determine factors influencing the policy of beef cattle farming, and to design the strategic plan. The study is intended to contribute information and ideas in relation to sustainable beef cattle farming and also provide inputs for policy makers to develop the management plan for beef cattle development in order to fulfill the national food security needs.

\section{Literature Review}

The findings of Achmad at el. (2013) [10] indicated the promising the condition of beef cattle development in South Sulawesi. Based on the IFE and EFE matrices weighted score and the evaluation of internal and external factors, the position for beef cattle development lies at the position of grow and build. They recommended government intervention for development and expansion of beef cattle development programs through incentives and policy support. Prasititi,(2012) [14] suggested alternative strategies for developing beef cattle agribusiness by adapting technology for high production, enhancing partnerships agribusiness in rearing, processing and marketing. Jasmal at el. (2011) [2] formulated a strategy of rice straw as ruminant feed resources and suggested to enhance regional livestock development programs. Hartono (2009) [6] increase farm income and protect cattle farm by proving subsidies, capital and services. Livestock agribusiness is an integrated and comprehensive system of livestock management that covers all activities of livestock production facilities including processing and marketing of farm products, required from institutional support (Rahardi and Hartono (2000) [6]. 
Saragih (2000) [15] indicated that beef cattle agribusiness needs technological development for improving agribusiness performance. Technology development covers wide range of activities including production, feeding, and management. In Bangladesh so far three studies on beef cattle production and marketing are conducted by Nabi (1998), Halim (1998) and Hasan (2006) [18], [19], [20]. They found beef cattle production and marketing as profitable business and recommend government actions for development agribusiness of beef cattle in our country but no study related to beef cattle development strategies was found in Bangladesh. Based on the literature review the following research gaps are identified

- Lack of research and development on beef cattle in Bangladesh

- Lack of cattle feeding technique

- Lack of high quality beef breed in Bangladesh

- Inadequate beef cattle supply

- Inefficient processing techniques led to production of poor quality beef

Based on these identified gaps, this study focuses on beef cattle development strategies is useful in our country.

\section{Background of the Study}

Beef cattle are one of the potential commodities in national development. In Bangladesh beef cattle play an important role as sources of animal protein, income and fertilizer, employment opportunities, utilization of agricultural waste and as savings for farmers. The cattle population is spread throughout the country. In certain areas, beef cattle are profitable agribusiness for rural farmers which facilitated to develop meat processing companies and its bi-products such as hides, bone, horns and hooves are the raw materials for the development of other industries. According to Foster and Burt (1992) [5] Development of meat processing companies is largely determined by the availability and distribution of livestock. The rationale of beef cattle development strategies are that: (i) rural poverty remains a major problem in Bangladesh and rural-urban income disparities are increasing; (ii) Bangladesh demand for beef cattle products is growing rapidly with urbanization, increasing income and changing food habits; (iii) with prices of beef increasing and likely to remain strong, small scale beef cattle farming provides an outstanding opportunity to generate regular income and improve rural livelihoods; (iv) a number of development schemes are taken by foreign donor agencies to improve livelihood through beef cattle enterprises in the study areas (v) rapidly growing awareness of the importance of beef cattle in social and economic improvement; (vi) well-targeted public investments in the beef cattle value chain have the potential to leverage significant private investments. However, it is clear that many elements of the enabling environment for beef cattle agribusiness development is lacking strategies in the study areas that can support effective policy formulation and mobilize resources for targeted investments in the sector. Consequently, beef cattle agribusinesses require a comprehensive strategy for cattle farmers. In this context, the study is undertaken to develop strategies for beef cattle agribusiness in Bangladesh.

\section{Materials and Methods}

The study was conducted in Pabna and Sirajganj districts. Two Upazilas namely Shatia from Pabna and Raigonj from Sirajgonj districts were selected because of the concentration of beef cattle fattening activity. Total sample size was 180 including beef cattle producers and different agribusiness actors (i.e. live cattle traders, brokers, butcher - cum -meat traders, meat processor and beef by-products traders etc). Convenience sampling technique was used for selection of respondents of the study and questionnaires survey, FGD, KII and observation methods were adapted for collection of primary data. Secondary data were also collected from the various sources. Results of the analysis were presented in the form of tables and matrix. Data were analyzed by using SPSS software.

In this study, the following techniques were used which were also used by David et al.(2009), Ananto et al.(2011), Achmad et al.(2012) and Prastutiet et al (2012) [4], [12], [10], [11], [14].

\subsection{Analyzing the SWOT Matrix}

\subsubsection{Identification of External and Internal Factors}

The first step is to capture information and identify internal and external factors relating to beef cattle enterprise, by conducting discussions and interviews using questionnaire. Internal factors include the strengths and weaknesses. External factors include the opportunities and threats.

\subsubsection{Designing External and Internal Factors Matrix}

The results of identification and analysis of those two factors become an external determinant using external factor evaluation matrix(EFE) and internal determinant using an internal factor evaluation matrix (IFE), which in turn will be given a rating that is weighted and ranked by using a weights and ratings determining questionnaire by the researcher

\subsection{Designing and Analysis of Qualitative Strategic Planning Matrix (QSPM)}

\subsubsection{Formulating Alternative Strategies}

The next step is matching which focuses on generate viable alternative strategy to integrate the result of external and internal factors in the initial steps. The tools used in the analysis are SWOT Matrix. This matrix combines opportunities and threats which can be match to the strengths 
and weaknesses to produce an alternative strategy, that is SO strategy, strategy WO, WT strategy, and ST strategy.

\subsubsection{Choosing Priority Strategy by QSPM}

The final step is making the decision to determine which strategies are feasible alternatives and the best, with Quantitative Strategies Planning Matrix (QSPM) analysis which had previously been given an Attractiveness Score questionnaire. QSPM matrix is using the results of the initial step and matching phase analysis. The main components are QSPM key factors, alternative strategies, the value of attractiveness (attractiveness score -AS), the total value of attractiveness (attractiveness Total Score - TAS), as well as the sum total value of attractiveness (attractiveness Sum Total Score). After the experts filled in a questionnaire determining the value of attractiveness (attractiveness Score) then the data is entered into the QSPM matrix.

\subsubsection{Improved Strategy for Developing the beef cattle agribusiness}

In this stage formulating beef cattle development strategies including issues/problems, interaction and actions by actors of agribusiness in the study areas of Bangladesh

\section{Results and Discussion}

The results of the present study are presented in following heading to develop effective beef cattle agribusiness strategies.

\subsection{Internal Factor Evaluation Matrix (IFE Matrix)}

IEF Matrix is a strategic management tool used for evaluation of strengths and weaknesses for internal factors affecting the development of beef cattle in study areas. From Table 1, it can be seen that the highest weight score is 0.256 which implies that factors that are effective are innovation. These are important internal factors which are effective to develop the beef cattle in northern Bangladesh to support the food estate program. The result also shows that the sum of total weight score is 2.610. Therefore, it can be concluded that the strategy of developing beef cattle in northern Bangladesh has been effective in using the strength and minimizing weakness factors which had contributed to negative impact similar to Gunawan (2001) [7]. Suryana (2009) [16] in his study also stated that in order to enhance the role of beef cattle as meat suppliers and livestock income sources, it is advisable to apply an intensive maintenance system with an improved feed management and improved quality of cattle with disease control.

As for the improvement of genetic quality of the female calves, it is suggested to keep them in the breeding area for subsequent use as grading up cattle. Increased interest and motivation of cattle ranchers to expand their business can be facilitated through incentives in production.

Table 1. IFE (Internal Factor Evaluations) Matrix

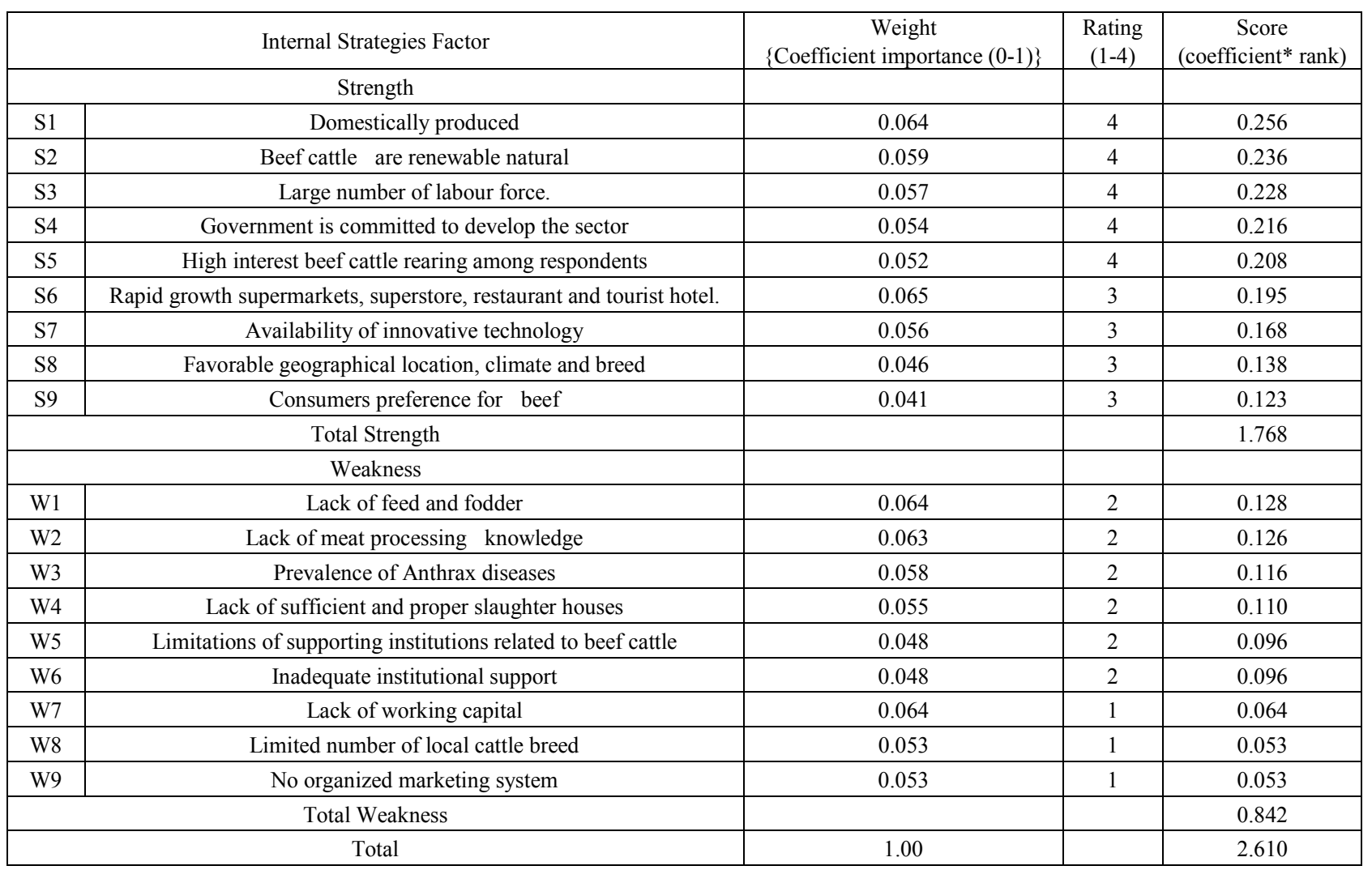


Table 2. EFE (External Factor Evaluations) Matrix

\begin{tabular}{|c|c|c|c|c|}
\hline & External Strategies Factor & $\begin{array}{c}\text { Weight } \\
\{\text { Coefficient importance } \\
(0-1)\}\end{array}$ & $\begin{array}{c}\text { Rating } \\
(1-4)\end{array}$ & $\begin{array}{c}\text { Score } \\
\text { (coefficient* } \\
\text { rank) } \\
\end{array}$ \\
\hline & Opportunities & & & \\
\hline $\mathrm{O} 1$ & Potential demand for beef over the country. & 0.071 & 4 & 0.284 \\
\hline $\mathrm{O} 2$ & Government support to develop beef cattle & 0.065 & 4 & 0.260 \\
\hline $\mathrm{O} 3$ & Domestic and foreign private sector interested to invest. & 0.074 & 3 & 0.222 \\
\hline $\mathrm{O} 4$ & High potential for profitable slaughter and processing business & 0.051 & 4 & 0.204 \\
\hline O5 & High value addition potential & 0.067 & 3 & 0.201 \\
\hline O6 & Consumers express more interest and are willing to pay for safe food & 0.061 & 3 & 0.183 \\
\hline O7 & $\begin{array}{l}\text { Domestic oriented processing plants have options to differentiate and diversify } \\
\text { their products to satisfy some of the untapped markets }\end{array}$ & 0.055 & 3 & 0.165 \\
\hline O8 & Labor intensive and employment opportunities & 0.041 & 4 & 0.164 \\
\hline O9 & Scope exists for developing backward and forward linkage. & 0.014 & 3 & 0.042 \\
\hline & Total Opportunities & & & 1.725 \\
\hline & Threats & & & \\
\hline $\mathrm{T} 1$ & Low productivity & 0.064 & 2 & 0.128 \\
\hline $\mathrm{T} 2$ & Increase in feed prices & 0.061 & 2 & 0.122 \\
\hline $\mathrm{T} 3$ & Increase in cattle prices & 0.046 & 2 & 0.092 \\
\hline $\mathrm{T} 4$ & Absence of pasture lands & 0.041 & 2 & 0.082 \\
\hline T5 & Poor access to credit & 0.065 & 1 & 0.065 \\
\hline T6 & High transportation cost (Illegal toll for cattle marketing) & 0.063 & 1 & 0.063 \\
\hline $\mathrm{T} 7$ & Beef cattle smuggling and Indian traders are selling cattle on credit & 0.061 & 1 & 0.061 \\
\hline $\mathrm{T} 8$ & Spread of cattle diseases & 0.057 & 1 & 0.057 \\
\hline T9 & $\begin{array}{l}\text { Lack of veterinary check of animal before and after slaughter and low } \\
\text { hygienic handling the meat lead to health risk for consumers }\end{array}$ & 0.043 & 1 & 0.043 \\
\hline & Total Threats & & & 0.713 \\
\hline & Total & 1.000 & & 2.438 \\
\hline
\end{tabular}

Source: Field Survey 2014

\subsection{External Factor Evaluation Matrix (EFE Matrix)}

EFE matrix is used the weighting scoring system to identify the value opportunity weight and threat for beef cattle producers in study area. Based on external evaluation matrix the results (Table 2) showed that the total score forthe opportunity factor is 1.725 and the threat is 0.713 and total score 2.438 indicate beef cattle agribusiness has a significant opportunity while minimizing threat in the study area which is similar to Achmad et al.(2012) [10] and Prastit. et al. (2012) [14].This is consistent with Nugroho (2006) [8] findings which states that the development of animal husbandry as a part of agricultural development will be associated with the reorientation of agricultural development policy. Animal husbandry development has new paradigms, namely alignment to people in general, responsibility delegation, structural change, and people empowerment. Therefore, it is necessary to formulate strategies and policies that are comprehensive, systematic, integrated both vertically and horizontally competitive, sustainable and decentralized.

\subsection{Internal External Matrix (IE Matrix)}

IE matrix is a simple analytical framework that is based on final summary of internal and external factors (IFE, EFE). It can specify appropriate strategy for the beef cattle agribusiness. Based on the evaluation of internal factors (IFE) and external factors (EFE) of the agribusiness, the following results were obtained:

Final score of internal factors evaluation matrix (IFE): 2.610

Final score of external factors evaluation matrix (EFE): 2.438

Here IFE $>$ EFE which indicates great opportunities to formulate the effective strategies for exploiting their strengths and minimize the weaknesses which is similar to Achmad et al.(2009) [10].and Riston (2008) [10]. Based on the research on model policy for beef cattle development, Achmad et al. (2009) [10] found the score of the internal and external factors was 2.603 and 3.457 , respectively. They point out that the government policy should be aimed at intensive programs, such as market penetration, market development and developing products. The other government policy should also be aimed at integration 
programs such as backward integration, forward integration and product integration.

\subsection{Formulating Alternative Strategies}

Here different types of strategies were transferred to the strategic planning table after the examination of specific components of SWOT. The SWOT model is comprised of a two-dimensional coordinate table; each of its four areas is the maker of a group of strategies.

Based on various findings of SWOT analysis, four strategies are formulated which are presented in Strategic Planning Table (Table-3) and are described below.
SO strategy or Aggressive: SO strategy was formulated by maximum use of environmental opportunities with application of strengths of the beef cattle agribusiness.

ST strategy or competitive: ST strategy was generated by using strengths of the beef cattle agribusiness to avoid facing threats.

WO Strategy or conservative: WO strategy was formulated by considering the potential advantages latent in environmental opportunities to make up for the weaknesses.

WT Strategy or defensive: WT strategy was formulated by considering minimizing loss from threats and weaknesses.

Table 3. Strategic planning table for alternative strategies

\begin{tabular}{|c|c|c|}
\hline SW & $\begin{array}{l}\text { Strength } \\
\text { S1. Domestically produced } \\
\text { S2. Beef cattle are renewable natural } \\
\text { S3. Large number of labour force. } \\
\text { S4. Govemment is committed to develop the sector } \\
\text { S5. High interest beefcattle rearing among } \\
\text { respondents } \\
\text { S6. Rapid growth supermarkets, supers tore, } \\
\text { restaurant and tourist hotel. } \\
\text { S7. Availability of innovative technology } \\
\text { S8. Favorable geograhical location, climate and } \\
\text { breed } \\
\text { S9. Consumers preference for beef }\end{array}$ & $\begin{array}{l}\text { Weakness } \\
\text { W1. Lack of feed and fodder } \\
\text { W2. Lack of meat processing lnowledge } \\
\text { W3. Prevalence of Anthrax diseases } \\
\text { W4. Lack of sufficient and proper } \\
\text { slaughter hou ses } \\
\text { W5. Limitations of supporting institutions } \\
\text { related to beef cattle } \\
\text { W6. Inadequate institutional support } \\
\text { W7. Lack of working capital } \\
\text { W8. Limited number of local cattle breed } \\
\text { W9. No organized marketing system }\end{array}$ \\
\hline $\begin{array}{l}\text { Opportunities } \\
\text { 01. Potential demand for beef over the } \\
\text { country. } \\
\text { O2. Government support to develop beef } \\
\text { cattle } \\
\text { O3. Domestic and foreign private sector } \\
\text { interested to invest. } \\
\text { 04. High potential for profitable slaughter } \\
\text { and processing business } \\
\text { O5. High value addition potential } \\
\text { 06. Consumers express more interest and } \\
\text { are willing to pay for safe food } \\
\text { 07. Domestic oriented processing plants } \\
\text { have options to differ entiate and diversify } \\
\text { their products to satis fy s ome of the } \\
\text { untappedmarkets } \\
\text { O5. Labor intensive and employment } \\
\text { opportunities } \\
\text { O9. Scope exists for developing backward } \\
\text { and forward linkage. }\end{array}$ & $\begin{array}{l}\text { SO Strategies (Aggressive) based on this sector's } \\
\text { advantages use external environment's pleas ant } \\
\text { opportunities: } \\
\text { SO1. ( } \mathrm{S} 1, \mathrm{~S} 2, \mathrm{~S} 3, \mathrm{~S} 4,01,02,03,04) \\
\text { Developing an integration strategy involving farmers, } \\
\text { value chain actors and meat proces sing industries. } \\
\text { This can improve productivity through trans ferring } \\
\text { beef fattening technologies; provide supports ervices } \\
\text { and sustainablemarket linkage. Developednew mat } \\
\text { processing farm or abattoirs by PPP model in } \\
\text { producing areas and determining strategies for } \\
\text { marketing with a goal of increasing domestic and } \\
\text { foreign markets share. } \\
\text { Short-term strategy }\end{array}$ & $\begin{array}{l}\text { WO Strategies(conservative)- by } \\
\text { improving sector's disadvantages us e } \\
\text { external environment's pleasant } \\
\text { opportunities } \\
\text { WO1. (W3, W4, W5, O1, O2,06) } \\
\text { Develop policy on sustainable intensive and } \\
\text { semi-intensive beef cattle production by } \\
\text { optimizing the principles of low external } \\
\text { input sustainable beef cattle based industry } \\
\text { and zero waste approaches of by-products } \\
\text { and also development contract framing } \\
\text { model with provision of self help group } \\
\text { formation, skill development, provide input } \\
\text { and finally market linkage. } \\
\text { Medium-term strategy }\end{array}$ \\
\hline $\begin{array}{l}\text { Threats } \\
\text { T1. Low productivity } \\
\text { T2. Increase in feed prices } \\
\text { T3. Increase in cattle prices } \\
\text { T4. Absence of pasture lands } \\
\text { T5. Poor access to credit } \\
\text { T6. High transportation cost (Illegal toll } \\
\text { for cattle marketing) } \\
\text { T7. Beef cattle smuggling and Indian } \\
\text { traders are selling cattle on credit } \\
\text { T8. Spread of cattle diseases } \\
\text { T9. Lack of veterinary check of } \\
\text { animal before and after slaughter andlow } \\
\text { hygienic handling the meat lead to health } \\
\text { risk for consumers }\end{array}$ & $\begin{array}{l}\text { ST Strategies(competitive)-based on sector's } \\
\text { advantages use overcoming opportunities of extemal } \\
\text { environment's non-pleasant influence } \\
\text { ST } 1 \text {. (S1,S2,S3, S7, T1,T4,T6) } \\
\text { Developmentcontract framingmodel with provision } \\
\text { of self help group formation, skill development, } \\
\text { provide input and finally market linkage and } \\
\text { increasing the role of safe guards to guarantee the } \\
\text { safeties of cattle fattening in legal way } \\
\text { Medium-term strategy }\end{array}$ & $\begin{array}{l}\text { WT Strategies(defensive) - by improving } \\
\text { its weak point in sector's external } \\
\text { environment's non-pleasant condition and } \\
\text { overcome its consequences } \\
\text { WT. 1. (W1, W2, W3, W5, T1,T5,T6) } \\
\text { Optimizing government role by supporting } \\
\text { programs, which increas agribusiness } \\
\text { potential with an integration system, } \\
\text { increas inglnowledge and ability of ranchers } \\
\text { by training programs and as sistance. } \\
\text { Long-term strategy }\end{array}$ \\
\hline
\end{tabular}

Source: Author own illustration 2014 


\subsection{Choosing Priority Strategy by the QSPM matrix}

QSPM matrix is made in order to choose and determine which strategy is the best to recommend to beef cattle development.

Based on the SWOT matrix analysis these strategies chosen to be implementing to the real condition of beef cattle development Table 4 shows that the value TAS is 5.833, which is chosen as best strategy to develop beef cattle agribusiness. The implementation of strategy IV is supported by strategies I, II and III because in order to streamline the provision of developing integrated strategy involving farmers, actors and meat processors in the value chain. These findings are consistent with the results of Ananto et al.(2011) [12]. Furthermore the researchers recommends improving beef productivity through transferring innovative beef fattening technology, increase support services and sustainable market linkage. New meat processing firms or abattoirs may be developed by share in model in producing areas and adopting marketing strategies for increasing cattle domestic and foreign markets share. This model should be supported by government through providing advanced technologies for fattening, feed processing and meat processing, which would lead to innovative beef cattle agribusiness

Table 4. Quantitative strategies planning matrix (QSPM)

\begin{tabular}{|c|c|c|c|c|c|c|c|c|c|c|}
\hline \multirow{3}{*}{$\begin{array}{l}\text { Sl. } \\
\text { No. }\end{array}$} & \multirow{3}{*}{ External and internal factors } & \multirow{3}{*}{$\begin{array}{c}\text { Weigh } \\
\mathrm{t}\end{array}$} & \multicolumn{8}{|c|}{ STRATEGY - SO } \\
\hline & & & \multicolumn{2}{|c|}{ Strategy-I } & \multicolumn{2}{|c|}{ Strategy-II } & \multicolumn{2}{|c|}{ Strategy-III } & \multicolumn{2}{|c|}{ Strategy-IV } \\
\hline & & & AS & TAS & AS & TAS & AS & TAS & AS & TAS \\
\hline & Opportunities & $\mathrm{a}$ & $\mathrm{b}$ & $\mathrm{C}=\mathrm{a} * \mathrm{~b}$ & $\mathrm{~d}$ & $\mathrm{e}=\mathrm{a} * \mathrm{~d}$ & $\mathrm{f}$ & $\mathrm{g}=\mathrm{a} * \mathrm{f}$ & $\mathrm{h}$ & $\mathrm{I}=\mathrm{a} * \mathrm{~h}$ \\
\hline $\mathrm{O} 1$ & Potential demand for beef over the country. & 0.014 & 3 & 0.042 & 4 & 0.056 & 4 & 0.056 & 2 & 0.028 \\
\hline $\mathrm{O} 2$ & Government support to develop beef cattle & 0.041 & 4 & 0.164 & 2 & 0.082 & 4 & 0.164 & 4 & 0.164 \\
\hline $\mathrm{O} 3$ & $\begin{array}{l}\text { Domestic and foreign private sector } \\
\text { interested to invest. }\end{array}$ & 0.061 & 3 & 0.183 & 3 & 0.183 & 3 & 0.183 & 3 & 0.183 \\
\hline $\mathrm{O} 4$ & $\begin{array}{l}\text { High potential for profitable slaughter and } \\
\text { processing business }\end{array}$ & 0.051 & 4 & 0.204 & 3 & 0.153 & 2 & 0.102 & 3 & 0.153 \\
\hline $\mathrm{O} 5$ & High value addition potential & 0.071 & 4 & 0.284 & 3 & 0.213 & 3 & 0.213 & 4 & 0.284 \\
\hline O6 & $\begin{array}{c}\text { Consumers express more interest and are } \\
\text { willing to pay for safe food }\end{array}$ & 0.074 & 3 & 0.222 & 4 & 0.296 & 2 & 0.148 & 4 & 0.296 \\
\hline $\mathrm{O} 7$ & $\begin{array}{l}\text { Domestic oriented processing plants have } \\
\text { options to differentiate and diversify their } \\
\text { products to satisfy some of the untapped } \\
\text { markets }\end{array}$ & 0.067 & 3 & 0.201 & 4 & 0.268 & 3 & 0.201 & 3 & 0.201 \\
\hline O8 & $\begin{array}{l}\text { Labor intensive and employment } \\
\text { opportunities }\end{array}$ & 0.065 & 4 & 0.260 & 3 & 0.195 & 3 & 0.195 & 3 & 0.195 \\
\hline O9 & $\begin{array}{l}\text { Scope exists for developing backward and } \\
\text { forward linkage. }\end{array}$ & 0.055 & 3 & 0.165 & 3 & 0.165 & 2 & 0.11 & 4 & 0.22 \\
\hline & Threats & & & & & & & & & \\
\hline $\mathrm{T} 1$ & Low productivity & 0.063 & 1 & 0.063 & 2 & 0.126 & 4 & 0.252 & 4 & 0.252 \\
\hline $\mathrm{T} 2$ & Increase in feed prices & 0.043 & 1 & 0.043 & 1 & 0.043 & 3 & 0.129 & 4 & 0.172 \\
\hline $\mathrm{T} 3$ & Increase in cattle prices & 0.065 & 1 & 0.065 & 3 & 0.195 & 3 & 0.195 & 3 & 0.195 \\
\hline $\mathrm{T} 4$ & Absence of pasture lands & 0.064 & 2 & 0.128 & 2 & 0.128 & 4 & 0.256 & 3 & 0.192 \\
\hline $\mathrm{T} 5$ & Poor access to credit & 0.061 & 2 & 0.122 & 3 & 0.183 & 4 & 0.244 & 4 & 0.244 \\
\hline T6 & $\begin{array}{l}\text { High transportation cost (Illegal toll for } \\
\text { cattle marketing) }\end{array}$ & 0.057 & 1 & 0.057 & 3 & 0.171 & 3 & 0.171 & 3 & 0.171 \\
\hline $\mathrm{T} 7$ & $\begin{array}{l}\text { Beef cattle smuggling and Indian traders are } \\
\text { selling cattle on credit }\end{array}$ & 0.046 & 2 & 0.092 & 3 & 0.138 & 3 & 0.138 & 4 & 0.184 \\
\hline $\mathrm{T} 8$ & Spread of cattle diseases & 0.041 & 2 & 0.082 & 2 & 0.082 & 3 & 0.123 & 3 & 0.123 \\
\hline T9 & $\begin{array}{l}\text { Lack of veterinary check of animal before } \\
\text { and after slaughter and low hygienic } \\
\text { handling the meat lead to health risk for } \\
\text { consumers }\end{array}$ & 0.061 & 1 & 0.061 & 3 & 0.183 & 4 & 0.244 & 4 & 0.244 \\
\hline & Strength & & & & & & & & & \\
\hline $\mathrm{S} 1$ & Domestically produced & 0.059 & 4 & 0.236 & 2 & 0.118 & 3 & 0.177 & 2 & 0.118 \\
\hline $\mathrm{S} 2$ & Beef cattle are renewable natural & 0.064 & 4 & 0.256 & 2 & 0.128 & 3 & 0.192 & 2 & 0.128 \\
\hline $\mathrm{S} 3$ & Large number of labour force. & 0.057 & 4 & 0.228 & 3 & 0.171 & 3 & 0.171 & 1 & 0.057 \\
\hline $\mathrm{S} 4$ & $\begin{array}{l}\text { Government is committed to develop the } \\
\text { sector }\end{array}$ & 0.065 & 3 & 0.195 & 3 & 0.195 & 2 & 0.130 & 2 & 0.130 \\
\hline S5 & $\begin{array}{l}\text { High interest beef cattle rearing among } \\
\text { respondents }\end{array}$ & 0.056 & 3 & 0.168 & 2 & 0.112 & 2 & 0.112 & 2 & 0.112 \\
\hline S6 & Rapid growth supermarkets, superstore, & 0.052 & 4 & 0.208 & 2 & 0.104 & 1 & 0.052 & 1 & 0.052 \\
\hline
\end{tabular}




\begin{tabular}{|c|c|c|c|c|c|c|c|c|c|c|}
\hline & restaurant and tourist hotel. & & & & & & & \\
\hline S7 & Availability of innovative technology & 0.046 & 3 & 0.138 & 3 & 0.138 & 3 & 0.138 & 2 & 0.092 \\
\hline S8 & $\begin{array}{c}\text { Favorable geographical location, climate } \\
\text { and breed }\end{array}$ & 0.054 & 4 & 0.216 & 3 & 0.162 & 2 & 0.108 & 3 & 0.162 \\
\hline S9 & Consumers preference for beef & 0.041 & 3 & 0.123 & 4 & 0.164 & 3 & 0.123 & 3 & 0.123 \\
\hline & Weakness & & & & & & & & & \\
\hline W1 & Lack of feed and fodder & 0.064 & 3 & 0.192 & 3 & 0.192 & 3 & 0.192 & 2 & 0.128 \\
\hline W2 & Lack of meat processing knowledge & 0.053 & 4 & 0.212 & 2 & 0.106 & 1 & 0.053 & 3 & 0.159 \\
\hline W3 & Prevalence of Anthrax diseases & 0.048 & 2 & 0.096 & 3 & 0.144 & 1 & 0.048 & 3 & 0.144 \\
\hline W4 & Lack of sufficient and proper slaughter & 0.063 & 2 & 0.126 & 3 & 0.189 & 2 & 0.126 & 4 & 0.252 \\
\hline W5 & Limouses & 0.058 & 2 & 0.116 & 4 & 0.232 & 2 & 0.116 & 2 & 0.116 \\
\hline W6 & Inadequate institutional support & 0.055 & 2 & 0.11 & 3 & 0.165 & 2 & 0.11 & 3 & 0.165 \\
\hline W7 & Lack of working capital & 0.064 & 2 & 0.128 & 2 & 0.128 & 2 & 0.128 & 3 & 0.192 \\
\hline W8 & Limited number of local cattle breed & 0.053 & 2 & 0.106 & 4 & 0.212 & 2 & 0.106 & 2 & 0.106 \\
\hline W9 & No organized marketing system & 0.048 & 3 & 0.144 & 4 & & 1 & 0.048 & 2 & 0.096 \\
\hline & Total of attractiveness score (TAS) & & & $\mathbf{5 . 4 3 6}$ & & $\mathbf{5 . 5 2 0}$ & & $\mathbf{5 . 2 5 4}$ & & $\mathbf{5 . 8 3 3}$ \\
\hline
\end{tabular}

N.B: Attractiveness score (AS) is: $1=$ not attractive, $2=$ somewhat attractive, $3=$ reasonably attractive, and $4=$ highly attractive

Table 5. Strategy to improve of beef cattle agribusiness

\begin{tabular}{|c|c|c|}
\hline Issue/Barriers/Problems & Interventions/Solutions & Actions taken by \\
\hline \multicolumn{3}{|c|}{ A. Technical problems and solution } \\
\hline $\begin{array}{l}\text { 1. Lack of beef breeds } \\
\text { 2. Lack of standard cattle fattening } \\
\text { technologies and feed ingredients at local } \\
\text { level } \\
\text { 3. Lack of veterinary service } \\
\text { 4. Marketing skill and capacity } \\
\text { 5. Use of unauthorized growth promoter } \\
\text { for cattle fattening } \\
\text { 6. Lack of slaughtering and processing } \\
\text { facilities }\end{array}$ & $\begin{array}{l}\text { 1. Development of beef breeds for increased productivity at farm level. } \\
\text { 2. Encourage the rural poor cattle farmers in cattle fattening using } \\
\text { improved technologies, quality beef production and establishing } \\
\text { linkages with markets actors. } \\
\text { 3. Increased ratio of vaccination and mapping for disease prediction } \\
\text { 4. Develop local service provider or private } \\
\text { 5. Use of fattening techniques towards organic cattle farming. } \\
\text { 6. Policy update to discourage used of growth promoter for fattening } \\
\text { 7. Arrangement of training for butchers on scientific methods of } \\
\text { slaughtering, meat processing and preservation technique. } \\
\text { 8.Bangladesh Agricultural Universities and Bangladesh Livestock } \\
\text { Research Institute should more emphasis on carryout research in } \\
\text { various aspects of cattle farming }\end{array}$ & $\begin{array}{c}\text { Government. } \\
\text { NGOs+ Government. } \\
\text { + Private enterprise } \\
\text { Government +DLS } \\
\text { DLS+ Veterinary } \\
\text { Universities+ NGOs+ } \\
\text { Private enterprise. } \\
\text { Government. } \\
\text { Government +DLS } \\
\text { Government. }\end{array}$ \\
\hline \multicolumn{3}{|c|}{ B. Economic problems and solution } \\
\hline $\begin{array}{l}\text { 1.Lack of working capital for beef cattle } \\
\text { agribusiness } \\
\text { 4. Lack of coordination of different } \\
\text { actors } \\
\text { 5. Lack of processing factory } \\
\text { 6. Lack of contract farming and self-help } \\
\text { groups }\end{array}$ & $\begin{array}{l}\text { 1. Arrangement of adequate amount of credit at low rate of interest. } \\
\text { 2. Facilitate and linking farmers with different agribusiness operators } \\
\text { (Company) and traders. } \\
\text { 3. Encourage entrepreneurs is establish meat processing factories in } \\
\text { north Bengal } \\
\text { 4. Organize self-help group for access to inputs and support service } \\
\text { with provision of contract farming. } \\
\text { 5. Development of backward and forward linkage system to help } \\
\text { improvement of existing cattle farming system into private enterprises. }\end{array}$ & $\begin{array}{l}\text { NGOs and Banks } \\
\text { NGOs +Dept. of Extension } \\
\text { Private enterprise } \\
\text { Farmers and NGOs } \\
\text { NGOs and Private sector }\end{array}$ \\
\hline \multicolumn{3}{|c|}{ C. Market problems and solution } \\
\hline $\begin{array}{l}\text { 1. Lack of cattle market infrastructure and } \\
\text { disposal system of waste products } \\
\text { 2. Lack of marketing and distribution } \\
\text { system } \\
\text { 3. Processing in unhygienic condition }\end{array}$ & $\begin{array}{l}\text { 1. Improve market infrastructure } \\
\text { 2. Transparence of price, transaction method and market information } \\
\text { between farmers and agribusiness actors } \\
\text { 3. Organize and upgrade meat distribution network } \\
\text { 4. Policies for good production practices of beef cattle fattening. } \\
\text { 5. Encourage private sector to establish mechanized slaughter house. }\end{array}$ & $\begin{array}{l}\text { Government. } \\
\text { Private enterprise }+ \text { media } \\
\text { Private enterprise } \\
\text { Government. } \\
\text { Government. }\end{array}$ \\
\hline
\end{tabular}

Source: Field survey 2014 


\subsection{Strategy to Improve Beef Cattle Agribusiness}

Table 5 provides a summary of key findings that impede the competitiveness of beef cattle agribusiness in the study areas necessary interventions doing with the concerned agencies for taking actions.

\section{Conclusions}

Based on SWOT analysis the weighted scores are1.725, $2.438,1.768$, and 0.842 for opportunities, threats, strength and weakness respectively. Opportunities and strength scores are higher than the threats and weakness of beef cattle agribusiness. The results indicate the great opportunity to explore the beef cattle agribusiness. From the QSPM matrix analysis results show that SO strategy is the best strategy among the four strategies and total attractiveness score (TAS) is 5.833. So the strategy IV is chosen and other strategies will support strategy IV. Some recommendations to enhance beef cattle agribusiness in the study area are forwarded below:

- $\quad$ Preparing strategic plans for beef cattle agribusiness combination with producer and meat processor by public private partnership.

- $\quad$ Formal production- marketing contract farming of beef cattle may be introduced.

- Encourage investment on commercial cattle fattening, meat processing, and butcher equipment and distribution network.

- Arrangement for access to institutional credit with reasonable interest rate may help to enhance production of beef cattle

- Introduction of suitable/appropriate vehicles for transportation of cattle during buying and selling

- Encourage donor agencies for taken development projects like Samiriddhi, SDVC, CLP, M4P, Value chain etc

- $\quad$ Raising awareness among the farmers, traders, value chain actors to use cattle fattening technology.

\section{Acknowledgements}

The authors are thankful to the beef cattle entrepreneurs and different agribusiness actors in the study areas who participated in the study. The author also thankful to $\mathrm{Mr}$. HannyJørgensen, Danish Agricultural Advisory Service (DAAS), Denmark for his valuable comments to improve the paper

\section{REFERENCES}

[1] A.M.M. Tareque, S.M.Z.H Chowdhury. Agricultural Research Priority: Vision-2030 and beyond, Bangladesh Agricultural Research council, Farmgate, Dhaka, Bangladesh, 2010
[2] A Jasmal. Syamsu, M. A. Hikmah, M. Ridwan, A Mawardi . Asia. Analysis of Sustainability Status of Integration of Beef Cattle and Paddy with Technology Innovation of Rice Straw as Feed and Beef Cattle Manure as Fertilizer and Biogas, Environment and Natural Resources J. Vol 11, No.2, 2013

[3] A.M. Bamualim, B. Trisnamurti, C Talib. Beef Cattle Development Direction in Indonesia, Journal of Agricultural Research, Vol.12, No.2, 22-28, 2008

[4] F.R. David.Strategic Management: Concepts and Cases, 12th edition, 2009.

[5] Foster KA, Burt OR. 1992. A Dynamic Model of Investment in The U.S. Beef-Cattle Industry. Journal of Business \& Economic statistics. Vol. 10, No. 4, 1992

[6] F.R. Rahardi, Hartono, (2003), Agribusiness Livestock, Jakarta: PenebarSwadayapp33.2003

[7] Gunawan. Model and Strategy of Agribusiness Research Cooperation on Beef Cattle in Globalization Period, Online available from

http://farmsolution.blogspot.com/2008/11/model-and-strateg y-of-agribusinness.html

[8] I.A.W Nugrohadi,(2009), Agribusiness Policy Analysis. Lecture Materials Doctoral Programme in Business Management IPB, 2009 [Not published]

[9] J. Kangas, M. Kurtila, M. Kajanus, A. Kangas.Evaluating the management strategies of aforestlandestate-theS-O-Sapproac h,Journal of Environmental Managemen,Vol.69,349-358, 2000 .

[10] M. Achmad, Hartoyo, B. Arifin, S.M. Didu. Model Policy Design for the Beef Cattle Development in South Sulawesi, ${ }^{\text {st }}$ Annual International Inter-disciplinary Conference,Bogor Agricultural University, Indonesia, 2012.

[11] M.E David, F.R. David. The Quantitative Strategic Planning Matrix (QSPM) Applied to a Retail Computer Store, The Coastral Business Journal, Vol. 8, No. 1, 42-52, 2009.

[12] N. Ananto, Eriyatno, Marimin, D. Arief. Model Integration Policy Development Planning Livestock-Beef Case Study of Self-Sufficiency, Journal of Development Planning, Vol.17, No.3, 2011.

[13] Nugroho BA. Livestock Agribusiness Development Support For The Productive Economics (Study at North Sulawesi). Journal For Agriculture Research and Development, Vol.16, 62-72, 2006

[14] R.A.Prastiti,W.Arip. Agribusiness Development Strategies of Beef Cattle in Blora District, Online available from http://agribisnis.fp.uns. ac. id

[15] Suragith. Development Of The Cattle Beef Business Agribusiness Based With The Partnership System. Journal For Agriculture Research and Development 28 (1) : 29-37. 2009

[16] Suryana, S.N.Taheri, A.M.Mighani. Model and Strategy of Agribusiness Research Cooperation on Beef Cattle in Globalization Period, Online available from http://www.ukessays.Com/essays business/swot-analysis.php

[17] T. Ekowati1, D.H. Darwanto, S. Nurtini, A. Suryantini. The analysis of beef cattle subsystem agribusiness implementation in central java province, Indonesia $\mathrm{J}$. 
Indonesian Trop. Anim. Agric. Vol. 36 No.4, 2011

[18] Nabi, N.N. A study on Beef cattle marketing in Bangladesh. MS thesis, Department of Co-operation and Marketing, Bangladesh Agricultural University, Mymensingh-2202,1998

[19] Halim, M.A. An Agribusiness study of beef and beef product in Dhaka city. MS thesis, Department of Co-operation and
Marketing, Bangladesh Agricultural University, Mymensingh-2202,1998

[20] Hasan, M.R. Study on cattle fattening and marketing systems and their improvement in the context of global meat market policy. MS thesis, Department of Co-operation and Marketing, Bangladesh Agricultural University, Mymensingh-2202,2006 